\title{
Improved immunological detection of Spongospora subterranea
}

\section{Journal Article}

\section{Author(s):}

Merz, U.; Walsh, J.; Bouchek-Mechiche, K.; Oberhänsli, Th.; Bitterlin, W.

Publication date:

2005-04

Permanent link:

https://doi.org/10.3929/ethz-b-000047664

\section{Rights / license:}

In Copyright - Non-Commercial Use Permitted

\section{Originally published in:}

European Journal of Plant Pathology 111(4), https://doi.org/10.1007/s10658-004-6330-7 


\title{
Improved immunological detection of Spongospora subterranea
}

\author{
U. Merz ${ }^{1}$, J.A. Walsh ${ }^{2}$, K. Bouchek-Mechiche ${ }^{3}$, Th. Oberhänsli ${ }^{4}$ and W. Bitterlin ${ }^{4}$ \\ ${ }^{1}$ Plant Sciences / Phytopathology Group, FIT, Universitätsstrasse 2, CH-8092 Zurich, Switzerland, (Fax: \\ +41-1-632 15 72; E-mail ueli.merz@ipw.agrl.ethz.ch); ${ }^{2}$ Warwick HRI, Wellesbourne, Warwick, CV35 9EF, \\ UK; ${ }^{3}$ INRA, UMR NiO3P, 35653 Le Rheu, France; ${ }^{4}$ BIOREBA AG, Chr. Merian-Ring 7, CH-4153 Reinach \\ BL1, Switzerland
}

Accepted 7 November 2004

Key words: Inoculum, monoclonal antibody, potato, quantification, watercress

\begin{abstract}
The genus Spongospora has two members which are important pathogens of vegetables, S. subterranea f.sp. subterranea $(S s s)$ and $S$. subterranea f.sp. nasturtii $(S s n)$. The close taxonomic relationship of these formae speciales is based on similar cystosori morphology. The potato disease powdery scab, caused by $S s s$, is difficult to control. The key control measure is avoidance, aimed at planting clean seed in clean soil. For the development of routine tests for the presence of the pathogen on tubers and in soil, a monoclonal antibody (MAb) was developed using Sss cystosori as immunogen. It detected less than one Sss cystosorus and recognised Sss material from many parts of the world. No cross-reactions with other Plasmodiophoromycetes including Plasmodiophora brassicae, Polymyxa betae, Polymyxa graminis and different Streptomyces species causing common and netted scab of potatoes were observed. A novel tuber sample test method was developed using a kitchen peeling machine. This detected two tubers with one powdery scab lesion each in a sample including eighteen uninfected tubers. When soil samples spiked with cystosori were tested with the MAb, different Sss infestation levels could be discriminated. Ssn cystosori gave absorbance values in ELISA as high as Sss cystosori, whereas fresh crook roots of watercress containing Ssn zoosporangia and plasmodia or mud from an Ssn infected watercress bed gave low absorbance values or no reaction. The potential of these findings for the development of a disease control management are discussed.
\end{abstract}

\section{Introduction}

The genus Spongospora, together with eight other genera, belongs to the division Plasmodiophoromycota, included in the Kingdom Protozoa (Braselton, 1995). As there is uncertainty about their systematic classification, the informal term Plasmodiophorids is used. Several Plasmodiophorids are important pathogens and most of the 'fungal' virus vectors belong to this group. The two most important members of Spongospora, S. subterranea f.sp. subterranea $(S s s)$ and $S$. subterranea f.sp. nasturtii $(S s n)$ are the only 'fungal' virus vectors that are also plant pathogens. Both are obligate parasites and spread via zoospores. Their resting spores (cystosori) have a characteristic spongiform-like structure which enables them to survive for a long time in the absence of host plants.

Once infested with Sss, soils can remain contaminated for up to 10 years. No effective control measures are available (Pitts, 2000). Many current potato cultivars are highly susceptible to powdery scab (Merz, 2000a). Breeding for resistance as a long term strategy has only been started recently (Falloon et al., 1999). Currently the most reliable control measure is prevention, which, in its most extreme, means planting clean seed into uncontaminated land. The traditional visual inspection of normally unwashed seed tubers runs the risk of misidentification (Merz, 2000b). Symptomless tuber contamination is also a risk. The contamination levels of field soils are difficult to determine. 
Although bioassays involving the baiting of soil samples with tomato (Merz, 1989) or potato (Wale et al., 1993) seedlings have been used, they are labour intensive and slow. Sensitive, rapid and reliable detection and quantification of cystosori of Sss (on tubers and in field soils) and of Ssn spores (in watercress bed soil) would be a useful tool to investigate the relationship between soil contamination levels and disease levels observed in the field, and also a great aid to the development of disease management strategies.

Serological and molecular techniques have been used to develop detection methods for Sss and Ssn. Harrison et al. (1993) described the development of an enzyme-linked immunosorbent assay (ELISA) with a polyclonal antibody (PAb) for the detection of Sss cystosori on potato tubers and Walsh et al. (1996) demonstrated detection in field soils with a PAb. Monoclonal antibodies (MAbs) produced against Sss zoospores did not detect cystosori (Wallace et al., 1995). Bulman and Marshall (1998) and Bell et al. (1999) designed molecular primers which detect small amounts of Sss, but detection in soil and quantification still need improvement. Most recently, van de Graaf et al. (2003) used realtime PCR with newly designed primers to detect and quantify $S s s$ in soil, water and plant tissue samples. Down and Clarkson (2002) developed a sensitive PCR-based detection system for Ssn but tested it mainly on zoospores.

This paper describes the sensitivity and specificity of a new monoclonal antibody developed against the cystosori of Sss, and its potential for detection of $S s s$ and $S s n$.

\section{Material and methods}

\section{Development of monoclonal antibodies}

\section{Preparation of antigen and immunization}

Cystosori of Sss were used as antigen and obtained from potato cv. Bintje grown in Switzerland. The cystosori preparation was made as described in Walsh et al. (1996). A mixture of intact cystosori, enzyme-treated cystosori and cystosori which had been homogenized with a pestle and mortar, suspended in $\mathrm{PBS}$ at $10 \mathrm{mg} \mathrm{ml}^{-1}$, was used to immunize female BALB/c mice (RCC Ltd, Füllinsdorf, Switzerland) three times sub-cutaneously with 3-6 week intervals between injections.
Injections consisted of $50-150 \mu \mathrm{l}$ of this spore suspension mixed with an equal volume of complete Freund's adjuvant for the first and with incomplete adjuvant for the subsequent injections.

\section{Cell fusion and selection}

Three to 5 days after the last boost injection, $3 \times 10^{7}$ spleen cells were fused with $5 \times 10^{7}$ myeloma cells (De St. Groth and Scheidegger, 1980). Fourteen to 26 days after the fusions, cell culture supernatants were repeatedly screened for Sssspecific antibodies in a plate-trapped antigen enzyme-linked immunosorbent assay (PTA-ELISA) or by triple antibody sandwich ELISA (TASELISA) with goat anti-mouse IgG-alkaline phosphatase for detecting reagent. For the latter test format, a polyclonal antibody from earlier studies on Sss was used (Walsh et al., 1996). For these screenings, spore suspensions (similar to those used for immunization) and $S s s$-infected potato tuber peelings were used as positive controls and healthy potato tuber peelings and extraction buffer were used for negative controls. Selected hybridomas that tested positive for resting spore solutions and for infected potato tubers were subcloned by limiting dilution.

\section{Development of ELISA reagents}

Monoclonal antibodies were produced in vitro. The IgG fraction was purified from cell culture supernatant by precipitation with saturated ammonium sulphate and subsequent Protein A affinity chromatography (Amersham Biosciences, Duebendorf, Switzerland). Labelling of $\mathrm{IgG}$ with alkaline phosphatase (Roche Diagnostics, Mannheim, Germany) was done according to the recommendations of the supplier of the enzyme. The reagents were optimized for use in the double antibody sandwich procedure (DAS-ELISA) using certified microtitre plates (Nunc Immuno Plates MaxiSorp F96, Gibco Ltd., Uxbridge, UK) and operating with a working volume of $200 \mu \mathrm{l}$ per well (Clark and Adams, 1977).

\section{ELISA}

To test the performance of the MAbs, a doubleantibody sandwich (DAS) ELISA was used. This was performed either by using the complete kit 
(Art. No. 111172, BIOREBA) containing all reagents, buffers, substrate, microtitre plates and applying a working volume of $200 \mu 1$ for all steps, or by using a modified protocol which is described below: The IgG (Art. No. 111112, BIOREBA) was diluted 1 in 1000 in $0.05 \mathrm{~mol} \mathrm{l}^{-1}$ sodium carbonate buffer (pH 9.6) and pipetted into each of 2 wells (200 $\mu \mathrm{l}$ per well) of microtitre plates (Nunc Immuno Plate MaxiSorp F96, Gibco Ltd., Uxbridge, UK) and incubated overnight $(16 \mathrm{~h})$ at $4{ }^{\circ} \mathrm{C}$. Subsequently the plates were incubated for $2 \mathrm{~h}$ at $37^{\circ} \mathrm{C}$ with sample homogenates $(150 \mu 1$ per well, ground for $1 \mathrm{~min}$ in extraction bags ('Universal') using a hand homogenizer (both BIOREBA AG, Reinach, Switzerland) for cystosori and plant material or with pestle and mortar for soil and peat in TRIS-buffered saline containing Tween 20 $(0.05 \%)$ and PVP (MW $25 \mathrm{kD}, 2 \% \mathrm{w} / \mathrm{v}$ ) (extraction buffer; $\mathrm{pH}=7.4)$ ). This was followed by $\mathrm{IgG}$ conjugated to alkaline phosphatase (Art. No. 111122, BIOREBA) diluted 1 in 1000 in TRISbuffered saline containing Tween $20(0.05 \% \mathrm{v} / \mathrm{v})$, PVP $(2 \% \mathrm{w} / \mathrm{v})$, BSA $(0.2 \% \mathrm{w} / \mathrm{v})$ and $\mathrm{MgCl}_{2}$ hexahydrate $(0.02 \% \mathrm{w} / \mathrm{v})(\mathrm{pH}=7.4,150 \mu \mathrm{l}$ per well) for $3 \mathrm{~h}$ at $37^{\circ} \mathrm{C}$. Finally the plates were incubated with substrate (2-nitrophenyl phosphate (Sigma 104 phosphatase substrate tablets; one per $5 \mathrm{ml}$ ) in $10 \%$ diethanolamine adjusted to $\mathrm{pH} 9.8$ with $\mathrm{HCl})(150 \mu \mathrm{l}$ per well $)$ at room temperature. The optical absorbance at $405 \mathrm{~nm}\left(\mathrm{~A}_{405}\right)$ was measured after $1 \mathrm{~h}$ with an Anthos Labtec HT2 microplate reader (Tech Gen International, London, UK) blanked against unused wells or appropriate uncontaminated material.

\section{Sensitivity}

A sub-sample of quantified cystosori material from potato $\mathrm{cv}$. Bintje was adjusted to a concentration of 100 cystosori per $200 \mu \mathrm{l}$ in extraction buffer and further diluted to obtain the following concentrations: $42.5,8.5,1.7,0.34,0.068$ and 0.013 cystosori per $200 \mu$ l. The same cystosori material and uninfested soil were used to prepare a dilution series containing 8000, 6000, 4000, 2000, 1000, 500 and 100 cystosori $\mathrm{g}^{-1}$ soil. A sample of $1 \mathrm{~g}$ of each dilution was ground in $2 \mathrm{ml}$ extraction buffer. Additionally a similar dilution series was made with cystosori alone.

The prepared soil sample containing $500 \mathrm{cy}-$ stosori $\mathrm{g}^{-1}$ was compared to a naturally infested field soil from a powdery scab trial site and a peat substrate used for minituber production, which turned out to be heavily infested. Other commercial peat substrates were included as controls.

\section{Specificity}

Equal amounts $(5 \mathrm{mg})$ of cystosori material collected by sieving $(120 \mu \mathrm{m}$ mesh size $)$ scrapings from contaminated tubers from Switzerland, Denmark, Sweden, Scotland, Japan, New Zealand, USA and Peru and peelings from infected potatoes from France, The Netherlands, Chile and Ecuador $(0.1 \mathrm{~g})$ were ground in $5 \mathrm{ml}$ extraction buffer.

Cross-reaction of the MAb with the main Streptomyces species pathogenic to potato; S. scabies (Lambert and Loria, 1989a), S. acidiscabies (Lambert and Loria, 1989b), S. europaeiscabiei, S. stelliscabiei (Bouchek-Mechiche et al., 2000 ) and $S$. turgidiscabies (Miyajima et al., 1998) causal agents of common scab, and $S$. reticuliscabiei (Bouchek-Mechiche et al., 2000) causal agent of netted scab was tested. Pure strains were grown in $5 \mathrm{ml}$ of tryptone-yeast extract broth (Pridham and Gottlieb, 1948) for $48 \mathrm{~h}$ at $25^{\circ} \mathrm{C}$ in the dark with shaking. The cultures were harvested by centrifugation at $3000 \mathrm{~g}$ for $10 \mathrm{~min}$. The pellets were resuspended in $2 \mathrm{ml}$ of ELISA extraction buffer.

The specificity of the antibodies was also tested against extracts from common scab lesions from three potato cultivars (Santé, Cardinal and Désirée) and against extracts from netted scab lesions from tubers of cv. Bintje. Extracts were prepared by cutting $1 \mathrm{~g}$ of lesion tissue from diseased tubers and grinding them with pestle and mortar in $5 \mathrm{ml}$ of ELISA extraction buffer for $1 \mathrm{~min}$. Then $200 \mu \mathrm{l}$ of each preparation were pipetted into duplicate wells of a microtitre plate (Nunc Immuno Plate MaxiSorp F 96, Gibco Ltd., Uxbridge, UK). Positive controls were freeze-dried extracts of Sss cystosori (supplied with the ELISA-reagent from BIOREBA AG, Switzerland), cystosori material from different potato cultivars (prepared as $20 \mathrm{mg}$ of cystosori material ground in $2 \mathrm{ml}$ extraction buffer) and extracts from powdery scab lesions (prepared as described above for common scab). Negative controls included extracts from healthy tubers (prepared from symptomless tubers as 
described for lesion extracts) and extraction buffer only (all $200 \mu$ per well).

Further cross-reaction was tested using samples of roots infected with the closely related Plasmodiophorid organisms, Plasmodiophora brassicae, Polymyxa betae and Polymyxa graminis $(0.1 \mathrm{~g}$ ground in $5 \mathrm{ml}$ extraction buffer).

The ability to detect cystosori from $S s n$ was also tested. Crooks from infected watercress roots, dried, stored and microscopically checked for the presence of cystosori $(5 \mathrm{mg}$ per $2 \mathrm{ml}$ ), as well as crooks from fresh plants and sieved soil from the same watercress bed $(1 \mathrm{~g}$ per $5 \mathrm{ml})$, were ground in extraction buffer.

\section{Potato tuber sample test procedure}

To evaluate a practical method for screening a sample of tubers for the presence of Sss, a commercial kitchen peeling machine (Lips Maschinen AG, Arni, Switzerland) was used. Different ratios of healthy tubers:peeled tubers with one lesion left per tuber, in a total of 20 tubers were processed: 20:0, 19:1, 18:2, 16:4, 12:8, 4:16. Each batch was processed in the peeling machine for $12 \mathrm{~s}$ whilst flushing with about $500 \mathrm{ml}$ of tap water. Two samples of $200 \mu \mathrm{l}$ from each treatment were then taken from the washings for ELISA.

\section{Statistical analysis}

The $\mathrm{A}_{405}$ values of the cystosori dilution series were analysed after ANOVA using Tukey's procedure (HSD) with $P=0.05$ and $n=6$ using the SYSTAT 10 program (Systat Software Inc., Richmond, California, USA).

\section{Results}

\section{Development of monoclonal antibodies}

From two fusions, 768 wells of fusion products resulted in 712 wells with growing colonies; 35 of them were positive in the initial screening when cell culture supernatant was assayed for Sss-specific antibodies. Most of the initially positive clones were either not stable or not specific for Sss. One hybridoma clone secreting Sss antibodies of subclass $2 \mathrm{~b}$ was finally obtained by multiple cloning

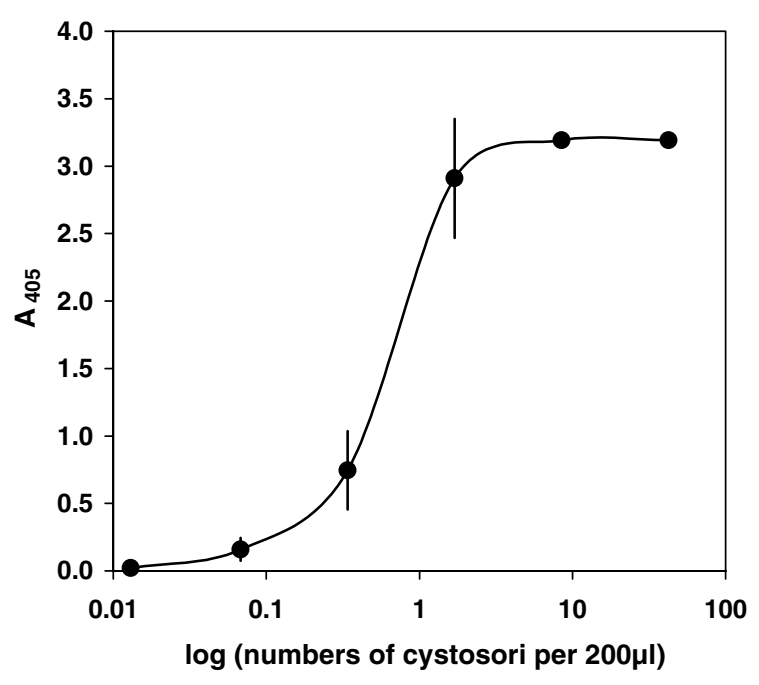

Figure 1. The relationship of the concentration of cystosori of Sss prepared from infected potatoes with $\mathrm{A}_{405}$ in DAS-ELISA. Mean data from 3 replicates and 2 ELISA plate wells each, blanked against negative control $(n=6)$. SD-bars.

under limited dilution and used for all subsequent experiments.

\section{Sensitivity}

The quantified cystosori reacted strongly in DASELISA. The data showed a linear relationship between 0.34 and 1.7 cystosori per well (Figure 1). The detection limit was at 0.068 cystosori per well. There was no significant difference between the $\mathrm{A}_{405}$ values for 0.013 and 0.068 cystosori $(P>0.05)$, however the $\mathrm{A}_{405}$ for 0.34 cystosori was significantly higher than that for 0.068 $(P<0.01)$. When artificially infested (spiked) soil was tested, the sample with 100 cystosori $\mathrm{g}^{-1}$ was discriminated from the uninfested control, but with an $\mathrm{A}_{405}$ value ten times lower than the $\mathrm{A}_{405}$ value of the equivalent amount of cystosori without soil (Figure 2). Hence, the detection limit was less than 1 cystosorus $\mathrm{ml}^{-1}$ extract when testing purified cystosori, but approximately 100 cystosori $\mathrm{g}^{-1}$ soil when testing spiked soil. Samples from a heavily infested trial site $\left(\mathrm{A}_{405}=0.63\right)$ and from peat substrate used for minituber production $\left(\mathrm{A}_{405}=0.50\right)$ gave higher $\mathrm{A}_{405}$ values than the 500 cystosori $\mathrm{g}^{-1}$ soil sample $\left(\mathrm{A}_{405}=0.12\right)$. Other peat substrates tested showed no reaction $\left(\mathrm{A}_{405}<0.005\right)$. 


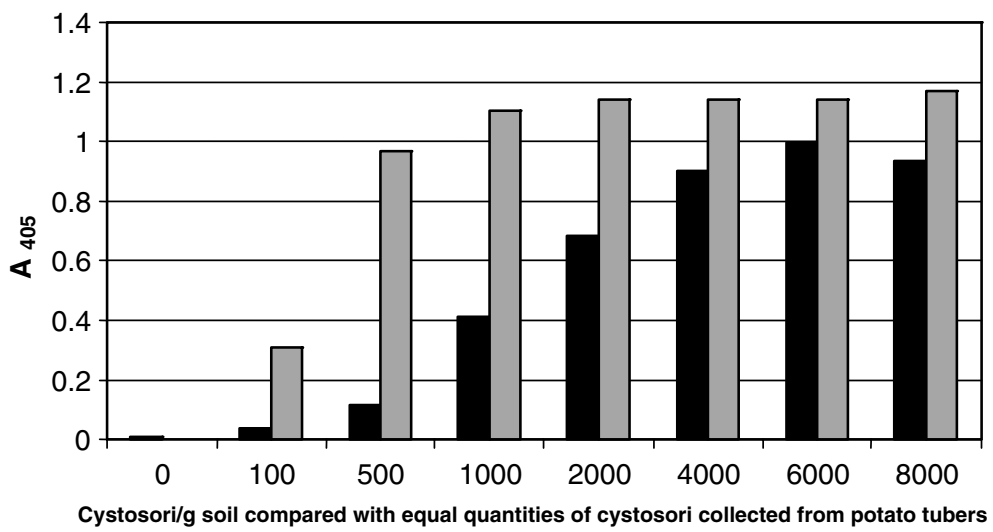

Soil + cystosori $\square$ Cystosori only

Figure 2. Absorbance $\left(\mathrm{A}_{405}\right)$ in DAS-ELISA of different numbers of cystosori of Sss in spiked soil samples compared with equal numbers of purified cystosori. Mean data from 2 wells.

\section{Specificity}

The Sss samples from Chile, Denmark, Ecuador, France, Japan, New Zealand, Peru, The Netherlands, Scotland, Sweden, Switzerland and USA gave similar positive $\mathrm{A}_{405}$ values. There was no

Table 1. Absorbance $\left(\mathrm{A}_{405}\right)$ in DAS-ELISA of extracts from pure Streptomyces cultures or from peelings of tubers showing common and netted scab symptoms using the MAb produced against the cystosori of powdery scab (Spongospora subterranea f. sp. subterranea)

\begin{tabular}{ll}
\hline Sample & $\mathrm{A}_{405}{ }^{1}$ \\
\hline Streptomyces species & \\
S. europaeiscabiei & $-0.33^{2}$ \\
S. stelliscabiei & -0.32 \\
S. scabies & -0.33 \\
S. acidiscabies & -0.34 \\
S. turgidiscabies & -0.34 \\
S. reticuliscabiei & -0.32 \\
Fresh peelings from potatoes with: & \\
common scab & -0.33 \\
netted scab & -0.32 \\
Positive Sss controls: & \\
$\quad$ cystosori inoculum & 2.31 \\
fresh peelings from tubers with powdery scab & 2.10 \\
freeze-dried peelings from tubers with & 1.55 \\
powdery scab & \\
Negative controls: & -0.21 \\
$\quad$ Fresh peelings from healthy tubers & -0.14 \\
$\quad$ extraction buffer & \\
\hline
\end{tabular}

${ }^{1}$ Mean data from 2 wells.

${ }^{2}$ Negative values due to blanking against empty (unused) wells. reaction of the MAb with pure cultures of six Streptomyces species or common and netted scab lesion extracts, whereas the positive Sss controls gave high $\mathrm{A}_{405}$ values (Table 1). Likewise no reaction was obtained when $P$. brassicae, $P$. graminis and $P$. betae were tested.

Dried and stored crooks from watercress roots containing cystosori of $S s n$ gave a similar $\mathrm{A}_{405}$ value compared to the same amount of a Swiss SSs cystosori homogenate $(S s n=1.39$, Sss $=1.43)$. Lower values were obtained when samples from fresh watercress roots with crook symptoms were tested $\left(\mathrm{A}_{405}=0.31\right.$ and 0.06$)$. Soil samples from the watercress beds where the infected plants had been taken, gave negative reactions.

\section{Potato tuber sample test procedure}

Only a slightly higher $\mathrm{A}_{405}$ value was obtained when $200 \mu \mathrm{l}$ samples of flushing water originating from the tuber sample with the lowest ratio (19 healthy:one tuber with a single lesion) were tested, compared to the healthy control $(\mathrm{HC}=0.022$, 19:1 = 0.028). Two tubers with one lesion each together with 18 healthy tubers gave a clear difference (Figure 3).

\section{Discussion}

This paper describes a monoclonal antibody $(\mathrm{MAb})$ produced against cystosori of Sss which 


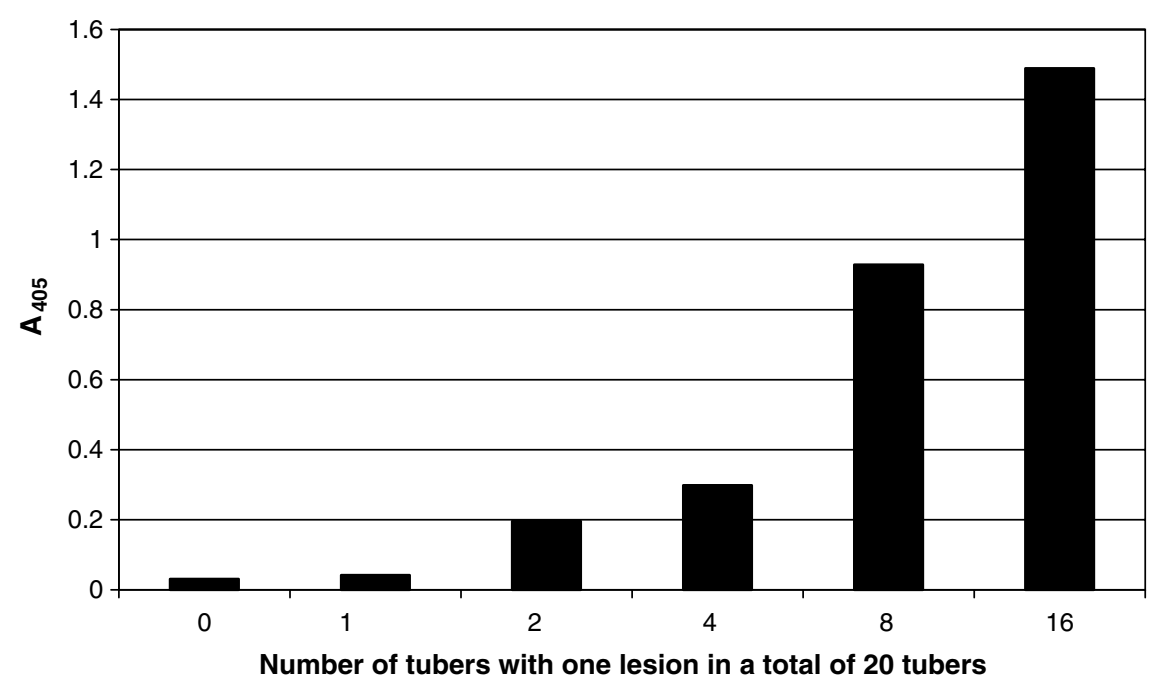

Figure 3. The $\mathrm{A}_{405}$ values in DAS-ELISA on batches of 20 potato tubers with different percentages of tubers peeled to leave one powdery scab lesion per tuber. The potato batches were processed in a potato peeling machine for $12 \mathrm{~s}$ and two samples $(200 \mu l$ each) of the flushing water $(500 \mathrm{ml})$ from each batch of potatoes were tested. Mean data from 2 wells.

detected Sss on tubers and in soil, but also verified the presence of cystosori of Ssn. Cystosori are the survival structures of both pathogens, found in soil and on tubers and transferred over long distances. Therefore, they are the main target for detection.

The sensitivity of the MAb in DAS-ELISA was similar to the highly sensitive polyclonal antibody (PAb), also produced against cystosori of Sss, tested in a PTA ELISA (Walsh et al., 1996). It detected less than one cystosorus which is sufficiently sensitive for the detection of tuber lesions. The advantage of a MAb is its unlimited supply and, related to this, its guaranteed reproducibility. Similar detection limits were found for PCR (Bell et al., 1999) and real-time PCR (van de Graaf et al., 2003).

The MAb provided a more linear relationship between the cystosori concentrations of less than $2000 \mathrm{~g}^{-1}$ soil in the spiked soils and $\mathrm{A}_{405}$ compared to that demonstrated earlier with the PAb (Walsh et al., 1996). In addition, the background reaction obtained from healthy soil was very low. But the comparison with the $\mathrm{A}_{405}$ values of the equivalent amounts of purified cystosori and cystosori in soil showed that in the presence of soil the detection limit of the MAb was slightly less than that of the $\mathrm{PAb}$. This may have been due to the matrix effect of soil components interfering with the antigenantibody interaction to some extent and thus masking the detection of cystosorus antigen.
Similar inhibition problems with their real-time PCR assay were reported by van de Graaf et al. (2003) when spiked soil was tested. They detected inoculum levels $<10$ cystosori $\mathrm{g}^{-1}$ soil, but the soil seemed to be already naturally contaminated. With conventional PCR and spiked soil, Bell et al. (1999) could detect $\geq 5$ cystosori $\mathrm{g}^{-1}$ soil consistently. Qu et al. (2000), using different primers and sieved soil $(500 \mu \mathrm{m}$ mesh), reported a detection limit of 4 cystosori $\mathrm{g}^{-1}$ soil. Preliminary experiments on the optimisation of the soil extraction method have shown that there is potential to further increase ELISA detection sensitivity and to improve significantly the current detection limit of 100 cystosori $\mathrm{g}^{-1}$ soil.

Both samples from the heavily infested soil and from one peat substrate gave much higher $\mathrm{A}_{405}$ values than the spiked soil sample with $500 \mathrm{cy}$ stosori $\mathrm{g}^{-1}$ soil. This supports the conclusion of Merz (1993) that heavily infested soils contain more than 500 cystosori $\mathrm{g}^{-1}$ soil. The heavy infestation of one of the peat substrates with SSS cystosori has been confirmed in a bioassay test that included other substrates and soils for comparison and all the appropriate controls (results not shown here). The findings are of special interest as this peat substrate is widely used for mini-tuber production. Here, the presence of any powdery scab infection means a big financial loss. This was one of the reasons why Rolot and Seutin (1999) 
suggested a soil-less production system. Natural peat material, built-up over thousands of years, originates from places where potatoes have never been produced. The other commercial peat substrates tested turned out to be Sss-free. The possible cause of the contamination of this particular substrate therefore needs to be investigated in order to avoid spread of Sss via the peat substrate and mini-tubers grown in it. The results show that ELISA testing of peat substrates using the MAb described in this paper would provide a rapid and sensitive means of identifying $S s s$ contaminated peat substrates prior to mini-tuber production.

Cystosori material from many countries and several continents were detected equally well by the MAb, demonstrating that they all possess the same epitope that is recognised by the MAb. Thus the MAb appears to have worldwide applicability.

A serious problem for the inspectors in the assessment of powdery scab infection levels on tubers is the similarity of symptoms caused by Streptomyces species which can be mistaken for powdery scab and vice versa, especially with unwashed material (Merz, 2000b). As the tolerance level for common scab is normally much higher than for powdery scab, there is a high probability that powdery scab infection levels of seed lots over the tolerance limit may go undetected and thus increase the risk of irreversible soil contamination. The availability of an antibody that has no crossreaction with any Streptomyces species, recognised so far as pathogenic to potato and responsible for powdery scab like symptoms, makes it an efficient tool for routine detection and objective determination of powdery scab on tubers. In practice, representative sub-samples of potato tuber lots are normally tested. Instead of laborious hand peeling of every single potato tuber for ELISA, the potato peeling machine used can handle 20-30 tubers at a time and the operation is easy and takes only a short time. The potato tuber test method described is sensitive enough to detect a few lesions in a subsample of 20 tubers. Once standardised, such a test could be used to investigate how tuber infection levels relate to disease thresholds defined by certification schemes.

PCR assays also have the potential for detecting tuber infection. Bulman and Marshall (1998) stated that the most suitable method to rinse tuber scab samples prior to DNA extraction. Qu et al. (1998) obtained a PCR product with DNA from symptomatic tubers of different cultivars but not from micropropagated mini-tubers. Bell et al. (1999) extracted DNA from peel of scabbed and apparently healthy tubers but only material from classified seed or axenically micropropagated tubers gave no amplification product. Additionally, they tested washings of symptomless and moderately scabbed tubers and concluded that there were cystosori present in both extracts. None of them tested a routine detection method based on PCR.

Tests on the thick-walled resting spore stage of other members of the Plasmodiophoromycetes demonstrated that they do not share the protein epitope of Sss that our MAb reacts with.

The cystosori of Sss and Ssn share a similar morphology. They also showed similarity in their immunological reaction against the MAb. The epitope recognised could be a wall protein common in both types of cystosori. In contrast to this, both Bulman and Marshall (1998) and Bell et al. (1999) did not find much homology between the DNA sequences of parts of the ITS region of each organism and the $S s n$ specific primers designed by Down and Clarkson (2002) failed to amplify DNA from Sss.

The cystosori of $S s s$ and $S s n$ are the main means of spread of powdery scab and crook root diseases respectively. Spread may result from the presence of the cystosori on potato tubers or by movement in contaminated soil. The cystosori are very resilient and able to survive in contaminated soil for many years in the absence of host plants. Consequently their detection and quantification are crucial for epidemiological studies and for control by disease avoidance (growing potatoes in fields where there are low levels, or no resting spores). Ssn cystosori can be found in roots of watercress plants as well as in the soil/mud in watercress beds; little is known about the role of the cystosori in the biology and epidemiology of crook root. Thus the new monoclonal antibody will provide a useful tool in future epidemiological studies on Sss and Ssn and for the first time will provide the opportunity for mass testing of potato tubers and field soils in order to control powdery scab. More information on soil infestation levels relative to powdery scab disease levels in the field is needed in order to define the necessary sensitivity range of a practical test method and also define threshold ELISA values for different levels of tuber infection. 
ELISA tests are cost-effective and used routinely (mostly for virus detection) in potato seed certification schemes, this should facilitate rapid uptake of the ELISA test we have described with the new monoclonal antibody by potato seed testing organisations worldwide. Further development and optimisation of soil extraction methods and the potato tuber test procedure could improve the detection limits and efficiency of ELISA testing of soils and tubers. Additionally it may be possible to use the MAb in an immunocapture-based PCR test (Nolasco et al., 1993), thereby increasing the sensitivity of PCR detection.

\section{Acknowledgements}

The authors thank Lisa Ward for supplying root material infected with $P$. graminis and $P$. betae cystosori, Orlando Andrade (Chile), John Larsen (Denmark), Corinne Fankhauser (Ecuador), Takato Nakayama (Japan), Richard Falloon (New Zealand), Herbert Torres (Peru), Wilbert Flier (The Netherlands), Julian Harrison (Scotland), Maria Sandgren (Sweden) and Krishna Mohan (USA) for supplying Sss cystosori material. The collaboration between U Merz and JA Walsh was made possible through joint Swiss National Science Foundation and British Council funding.

\section{References}

Bell KS, Roberts J, Verrall S, Cullen DW, Williams NA, Harrison JG, Toth LK, Cooke DEL, Duncan JM and Claxton JR (1999) Detection and quantification of Spongospora subterranea f.sp. subterranea in soils and on tubers using specific PCR primers. European Journal of Plant Pathology 105: 905-915.

Bouchek-Mechiche K, Gardan L, Normand P and Jouan B (2000) DNA relatedness among strains of Streptomyces pathogenic to potato in France: Description of three new species, S. europaeiscabiei $\mathrm{sp}$. nov. and $S$. stelliscabiei $\mathrm{sp}$. nov. associated with common scab, and $S$. reticuliscabiei sp. nov. associated with netted scab. International Journal of Systematic and Evolutionary Microbiology 50: 91-99.

Braselton JP (1995) Current status of the Plasmodiophorids. Critical Reviews in Microbiology 21: 263-275.

Bulman SR and Marshall JW (1998) Detection of Spongospora subterranea in potato tuber lesions using the polymerase chain reaction (PCR). Plant Pathology 47: 759-766.

Clark MF and Adams AN (1977) Characteristics of the microplate method of enzyme-linked immunosorbent assay for the detection of plant viruses. Journal of General Virology 34: 475-483.

De St. Groth S and Scheidegger D (1980) Production of monoclonal antibodies: Strategy and tactics. Journal of Immunological Methods 35: 1-21.

Down GJ and Clarkson JM (2002) Development of a PCRbased diagnostic test for Spongospora subterranea f.sp. nasturtii, the causal agent of crook root of watercress (Rorippa nasturtium-aquaticum). Plant Pathology 51: 275-280

Falloon R, Genet R, Wallace A and Nott H (1999) IPM use for powdery scab. Commercial Grower 54: 33-34.

Harrison JG, Rees EA, Barker H and Lowe R (1993) Detection of spore balls of Spongospora subterranea on potato tubers by enzyme-linked immunosorbent assay. Plant Pathology 42: 181-186.

Lambert DH and Loria R (1989a) Streptomyces scabies sp. nov. nom. International Journal of Systematic Bacteriology 39: 387-392.

Lambert DH and Loria R (1989b) Streptomyces acidiscabies sp. nov. nom. International Journal of Systematic Bacteriology 39: 393-396.

Merz U (1989) Infectivity, inoculum density and germination of Spongospora subterranea resting spores: A solution-culture test system. EPPO Bulletin 19: 585-592.

Merz U (1993) Epidemiological aspects of powdery scab of potatoes caused by Spongospora subterranea. Proceedings of the 2nd Symposium of the International Working Group on Plant Viruses with Fungal Vectors (pp 104-106) Montreal, Canada.

Merz U (2000a) Potato production and powdery scab situation in Switzerland. Proceedings of the First European Powdery Scab Workshop (pp 15-17) SAC, Aberdeen, Scotland (www.pa.ipw.agrl.ethz.ch/spongospora/EUworkshop/proceedings.html).

Merz U (2000b) Powdery scab control in Switzerland. Proceedings of the First European Powdery Scab Workshop (pp 43-44) SAC, Aberdeen, Scotland, UK.

Miyajima K, Tanaka F, Takeuchi T and Kuninaga S (1998) Streptomyces turgidiscabies sp. nov. International Journal of Systematic Bacteriology 48: 495-502.

Nolasco G, de Blas C, Torres V and Ponz F (1993) A method combining immunocapture and PCR amplification in a microtiter plate for the detection of plant viruses and subviral pathogens. Journal of Virological Methods 45: 201-218.

Pitts T (2000) Summary of the session of present control measures. Proceedings of the First European Powdery Scab Workshop (pp. 31-33) SAC, Aberdeen, Scotland, UK.

Pridham TG and Gottlieb D (1948) The utilisation of carbon compounds by some Actinomycetales as an aid for species determination. Journal of Bacteriology 56: 107-114.

Qu XS, Kavanagh JA and Egan D (1998) Development of specific and sensitive primers for the identification of Spongospora subterranea f.sp. subterranea. Faculty of Agriculture, University College, Dublin, National University of Ireland. (p. 206) Research Report 1996-1997.

Qu XS, Kavanagh JA and Egan D (2000) Quantification of the fungal cause of potato powdery scab in soil using a competitive polymerase chain reaction assay (pp 74-76) Faculty of Agriculture, University College, Dublin, National University of Ireland. Research Report 1998-1999. 
Rolot JL and Seutin H (1999) Soilless production of potato minitubers using a hydroponic technique. Potato Research 42: $457-469$.

van de Graaf P, Lees AK, Cullen DW and Duncan JM (2003) Detection and quantification of Spongospora subterranea in soil, water and plant tissue samples using real-time PCR. European Journal of Plant Pathology 109: 589-597.

Wale SJ, Burgess PJ and Burnett F (1993) Bioassay for Spongospora subterranea detection in soil and its potential use in predicting powdery scab in the field. Proceedings of 6th International Congress of Plant Pathology (p 281) Montreal, Canada.

Wallace A, Williams NA, Lowe R and Harrison JG (1995) Detection of Spongospora subterranea using monoclonal antibodies in ELISA. Plant Pathology 44: 355-365.

Walsh JA, Merz U and Harrison JG (1996) Serological detection of spore balls of Spongospora subterranea and quantification in soil. Plant Pathology 45: 884-895. 